九州大学学術情報リポジトリ

Kyushu University Institutional Repository

\title{
Linkage Studies in Rice (Oryza sativa L.) : On Some Mutants for Physiological Leaf Spots
}

Iwata, Nobuo

Laboratory of Plant Breeding, Faculty of Agriculture, Kyushu University

Omura, Takeshi

Laboratory of Plant Breeding, Faculty of Agriculture, Kyushu University

Satoh, Hikaru

Laboratory of Plant Breeding, Faculty of Agriculture, Kyushu University

https://doi.org/10.5109/23671

出版情報：九州大学大学院農学研究院紀要. 22 (4)，pp.243-251，1978-07. Kyushu University バージョン：

権利関係 : 


\title{
Linkage Studies in Rice (Oryza sativa L.) On Some Mutants for Physiological Leaf Spots
}

\author{
Nobuo Iwata, Takeshi Omura and Hikaru Satoh \\ Laboratory of Plant Breeding, Faculty of Agriculture, \\ Kyushu University 46-01, Fukuoka 812
}

(Received April 21, 1978)

\begin{abstract}
Nine of the physiological leaf spot mutants were described and investigated linkage relation with marker genes. All of them were governed by single recessive genes respectively and the causal genes were designated as a series of $s p l$ (spotted leaves) as $s p l_{1}, s p l_{2} \cdots \cdots s p l_{9}$.

With eight of them except for $s p l_{9}$, the linkage groups were determined as follows: $s p l_{1}$ - a linkage group corresponding to A type of trisomics which never corresponded to any of twelve linkage groups published by Nagao and Takahashi, @\&-linkage group X, $s p l_{3}-\mathrm{XI}, s p l_{4}-\mathrm{I}, s p l_{5}-\mathrm{IV}, s p l_{6}-\mathrm{III}, s p l_{7}$ and $s p l_{8}-\mathrm{IX}$.
\end{abstract}

\section{INTRODUCTION}

Several mutants for physiological leaf spots, which is characterized by reddish or blackish brown spots and discolorations of leaves, stems and sometimes glumes were reported in rice and causal genes of them have been designated as a series of $b l$ (Jones, 1952; Nagao and Takahashi, 1963; Nagao et al., 1964; Takahashi et al., 1968).

On the other hand, the authors reported some mutants showing physiological leaf spots and designated the causal genes as a series of $s p l$ (spotted leaves) in order to avoid the confusions of them with the $b l$ mutants reported previously and to include any mutants for physiological leaf spots into a series of gene symbol regardless of the color of leaf spots. Namely, they are $s p l_{1}$ (Iwata and Omura, 1975), $s p l_{2}$ (Omura and Iwata, 1972) and $s p l_{3}, s p l_{4}$ and $s p l_{5}$ (Iwata and Omura, 1977).

This paper deals with nine mutants of the physiological leaf spots including these.

\section{MATERIALS AND METHODS}

The mutants used are shown in Table 1. All of them are governed by single recessive genes, respectively.

Two mutants, $s p l_{1}$ and $s p l_{2}$, are originated from spontaneous mutation. Four, $s p l_{3}, s p l_{4}, s p l_{5}$ and $s p l_{7}$, were induced in the gamma-field of Institute of Radiation Hreeding, National Institute of Agricultual Science, and $s p l_{9}$ is also a induced mutant by irradiation and was introduced from Division of Genetics, National Institute of Agricultural Science. Two, $s p l_{6}$ and $s p l_{3}$, were 
Table 1. List of physiological leaf spot mutants used and their causal genes.

\begin{tabular}{|c|c|c|c|c|}
\hline Strain number & Original variety & Source & Gene & symbol \\
\hline HO 698 & Banshinriki-byogata ${ }^{1)}$ & Spontaneous & & $s p l_{1}$ \\
\hline HO 696 & Katsumonbyo ${ }^{1)}$ & " & & $s p t_{2}$ \\
\hline M $\quad 41$ & Norin 8 & r-ray (chronic) & & $s p l_{3}$ \\
\hline M 114 & $\prime \prime$ & " & & $s p l_{4}$ \\
\hline M 87 & $"$ & $"$ & & $s p l_{5}$ \\
\hline CM 20 & Kinmaze & Chemicals & & $s p l_{6}$ \\
\hline M 64 & Norin 8 & r-ray (chronic) & & $s p \bar{l}_{7}$ \\
\hline CM 207 & Kinmaze & Chemicals & & $s p l_{8}$ \\
\hline L T 26 & Norin 8 & r-ray (acute) & & $s p l_{9}$ \\
\hline
\end{tabular}

1) Not original variety but name of mutant line.

induced by a chemical mutagen, N-nitroso-N-methylurea, at Kyushu University.

The phenotypic characteristics of the mutants are as follows.

$s p l_{1}$ : Large reddish brown spots on leaves and stems, of which appearance begins in the seedling stage and continues to heading time.

$s p l_{2}$ : Partial discoloration of leaves and stems. It appears from the seedling stage, but it is not so obvious in this stage and become more distinct in the tillering stage. Somewhat poor viability,

$s p l_{3}, s p l_{5}$ and $s p l_{7}$ : Relatively small reddish brown spots scattering over the whole surface of leaves. They appear from tillering stage to heading time. Their phenotypes are so resemble that it is difficult to distinguish each other.

$s p l_{4}$ : Relatively large reddish brown spots scattering on leaves, but not so much spots as $s p l_{3}, s p l_{5}$ and $s p l_{7}$.

Table 2. List of marker genes and their linkage groups.

\begin{tabular}{|c|c|c|c|}
\hline $\begin{array}{l}\text { Linkage } \\
\text { group }\end{array}$ & $\begin{array}{c}\text { Gene } \\
\text { symbol }\end{array}$ & Character & Reference \\
\hline I & $\begin{array}{l}w x \\
d p_{1}\end{array}$ & $\begin{array}{l}\text { waxy endosperm } \\
\text { depressed palea } 1\end{array}$ & Nagamatsu and Omura (1962) \\
\hline III & $\begin{array}{l}e g \\
\operatorname{lax} \\
d \\
\text { A" }\end{array}$ & $\begin{array}{l}\text { extra glume } \\
\text { lax panicle } \\
\text { tillering dwarf } \\
\text { anthocyanin activator }\end{array}$ & $\begin{array}{l}\text { Iwata and Omura (1971a) } \\
\text { Nagao and Takahashi (1963) }\end{array}$ \\
\hline IV & $\begin{array}{l}d_{6} \\
g \\
\mathrm{RC}\end{array}$ & $\begin{array}{l}\text { lop-leaved dwarf } \\
\text { long empty glumes } \\
\text { brown pericarp }\end{array}$ & " \\
\hline IX & $\begin{array}{l}a l_{K-2} \\
n l_{1} \\
r i\end{array}$ & $\begin{array}{l}\text { albino Kyushu-2 } \\
\text { neck leaf } 1 \\
\text { verticillate arrangement of rachis }\end{array}$ & $\begin{array}{l}\text { Iwata and Omura (1978) } \\
\text { Nagao and Takahashi (1963) } \\
\text { " }\end{array}$ \\
\hline $\mathbf{x}$ & $\begin{array}{l}d_{W} \\
g h_{2}\end{array}$ & $\begin{array}{l}\text { "Waisei-shirasasa" dwarf } \\
\text { gold hull } 2\end{array}$ & Iwata and Omura (1971b) \\
\hline XI & $\begin{array}{l}b c_{1} \\
d l\end{array}$ & $\begin{array}{l}\text { brittle culm } 1 \\
\text { drooping leaf }\end{array}$ & " \\
\hline
\end{tabular}


$s p l_{6}$ : Relatively large reddish brown spots on leaves and it is similar to $s p l_{4}$.

$s p l_{8}$ : Fine striped spots of reddish brown on whole surface of leaves, it appears after tillering stage.

$s p l_{9}$ : Small blackish brown spots on leaves and stems but not so thick, and it appears after heading time.

The mutant strains were crossed with linkage testers having marker genes shown in Table 2, and the linkage relations were tested in $\mathrm{F}_{2}$. In some cases, doubly recessive plants obtained from the above crosses were used for crossing. When the linkage was detected, the recombination value was estimated from the segregations in $F_{2}$ and in some cases in $F_{3}$ progenies by the method of maximum likelihood. The weighted mean was calculated when the recombination values were estimated from $F_{2}$ in both phase and $F_{3}$.

\section{RESULTS AND DISCUSSION}

$s p l_{1}$ : As shown in Table 3, the $s p l_{1}$ exhibited trisomic segregation in a cross with A type of trisomics (Iwata and Omura, 1975). Namely, a observed ratio of normal to $s p l_{1}$ in $F_{2}$ derived from trisomic $F_{1}$ plants was about 13: 1 that fitted well to a theoretical ratio of trisomic segregation being between 44: 1 and 3: 1 . On the other hand, a segregation of $F_{2}$ derived from disomic $F_{1}$ plants of the same cross fitted well to $3: 1$ ratio. So, it is concluded that the $s p l_{1}$ composes a linkage group with three genes, $r l_{1}, d_{B}$ and $n a l_{2}$, reported previously, though the group does not correspond to any of the groups published by Nagao and Takahashi (1963).

Table 3. Trisomic and disomic segregations of $s p l_{1}$ in $F_{2}$ of cross with $A$ type of trisomics.

\begin{tabular}{|c|c|c|c|c|c|}
\hline \multirow{2}{*}{$F_{1}$ plants } & \multicolumn{3}{|c|}{ Observed number } & \multirow{2}{*}{$\begin{array}{c}\chi_{3}^{2} \text { for } \\
31\end{array}$} & Ratio of domi.: rece. \\
\hline & Dominant & Recessive & Total & & Theoretical Observed \\
\hline Trisomic & 440 & 33 & 473 & $81.946 * * *$ & 8: $1-44: 113.3: 1$ \\
\hline Disomic & 365 & 118 & 483 & 0.084 & $3: 1$ \\
\hline
\end{tabular}

*** Significant at $0.1 \%$ level.

$s p l_{2}$ : A linkage relation was observed between $s p l_{2}$ and $g h_{2}$. From $F_{2}$ data shown in Table 4 , the recombination values of $s p l_{2}-g h_{2}$ were estimated at $17.5 \%$ from coupling phase, $15.2 \%$ from repulsion phase and thus weighted mean of $16.8 \%$ was obtained from them. It has been proved that $g h_{2}$ locates on the chromosome 8 corresponding to the linkage group $\mathrm{X}$ by the translocation method and that $g h$, links with $d_{w}$ with intensity of $31.2 \%$ (Iwata and Omura, $1971 \mathrm{~b}$ ). However, a clear linkage relation was not observed between $s p l_{2}$ and $d_{w}$, showing the recombination value of $47.8 \%$. Therefore, the sequence of the three genes at the map of the linkage group $\mathrm{X}$ may be $s p l_{2}-g h_{2}-d_{W}$ (Fig. 1). 


\section{N. Iwata et al.}

Table 4. Linkage relations between $s p l_{2}$ and genes belonging to the linkage group $\mathrm{X}$.

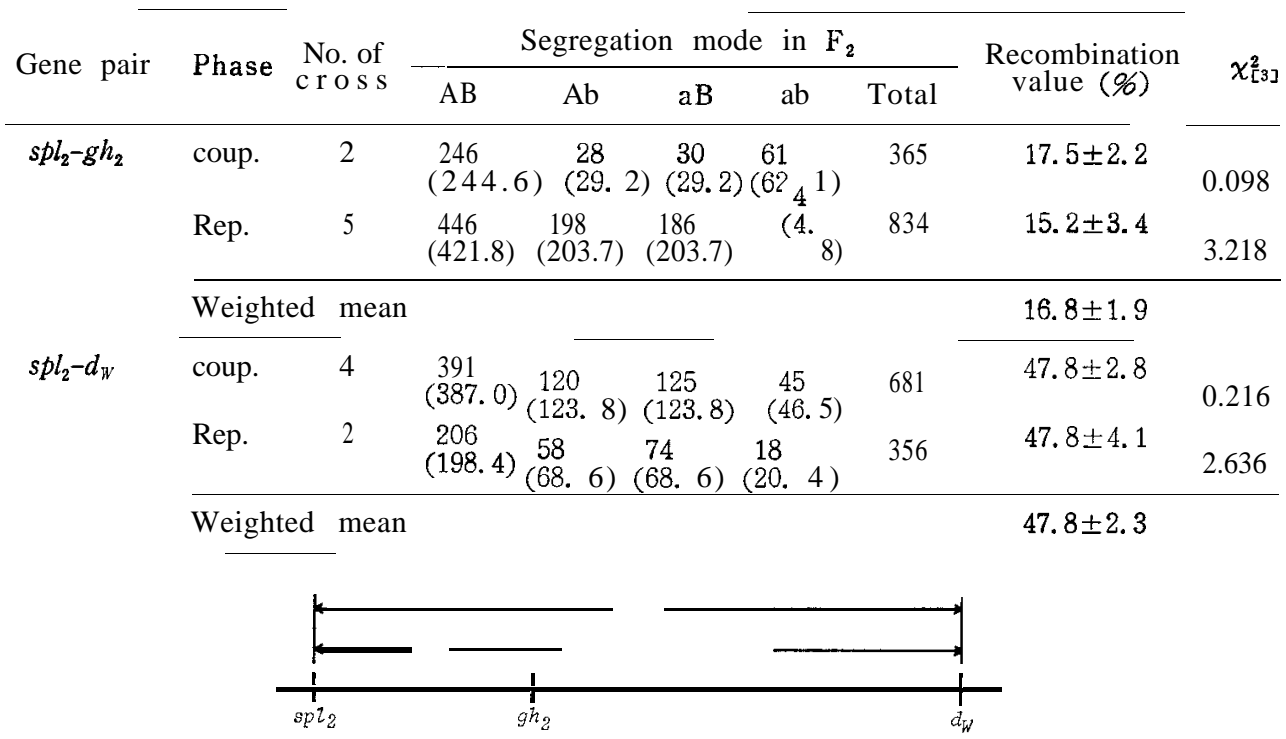

Fig. 1. Linkage map of the group $\mathrm{X}$.

$s p l_{3}$ : The linkage relations were found in $F_{2}$ of crosses between $s p l_{3}$ and such two genes as $d l$ and bc, belonging to the linkage group XI. From $F_{2}$ data shown in Table 5 , the recombination values of $s p l_{3}-d l$ were estimated at $15.8 \%$ in coupling phase, $19.1 \%$ in repulsion phase and thus their weighted mean of $16.5 \%$. The recombination value of $s p l_{3}-b c_{1}$ was estimated at

Table 5. Linkage relations between $s p l_{3}$ and genes belonging to the linkage group XI.

\begin{tabular}{|c|c|c|c|c|c|c|c|c|c|}
\hline \multirow{2}{*}{ Gene pair } & \multirow{2}{*}{\multicolumn{2}{|c|}{$\mathrm{Ph}$ as e $\mathrm{No}_{\mathrm{C}_{\text {ross }} \text { of }}$}} & \multicolumn{5}{|c|}{ Segregation mode in $F_{2}$} & \multirow{2}{*}{$\begin{array}{l}\text { Recombination } \\
\text { value }(\%)\end{array}$} & \multirow{2}{*}{$x_{[3]}^{2}$} \\
\hline & & & $\mathrm{AB}$ & $\mathrm{Ab}$ & $\mathrm{aB}$ & $\mathrm{ab}$ & Total & & \\
\hline \multirow[t]{3}{*}{$s p l_{\mathrm{s}}-d l$} & coup. & 7 & $\begin{array}{l}941 \\
(914.1)\end{array}$ & $\begin{array}{l}103 \\
(98.4)\end{array}$ & (98. & $(239$. & 1,350 & $15.8 \pm 1.1$ & 3.968 \\
\hline & Rep. & 10 & $\begin{array}{c}1,183 \\
(1,139.0)\end{array}$ & $\begin{array}{l}506 \\
(539.5)\end{array}$ & $\begin{array}{l}531 \\
(539.5) \\
\end{array}$ & (20. 0$)$ & 2,238 & $19.1 \pm 2.0$ & 3.058 \\
\hline & Weighted & mean & & & & & & $16.5 \pm 1.0$ & \\
\hline$s p l_{3}-b c_{1}$ & Rep. & 1 & $\begin{array}{l}101 \\
(99.4\end{array}$ & $\begin{array}{l}28 \\
(37.1\end{array}$ & $\begin{array}{c}45 \\
(37.1)\end{array}$ & $\begin{array}{l}8 \\
(8.4)\end{array}$ & 182 & $43.0 \pm 6.0$ & 3.960 \\
\hline
\end{tabular}

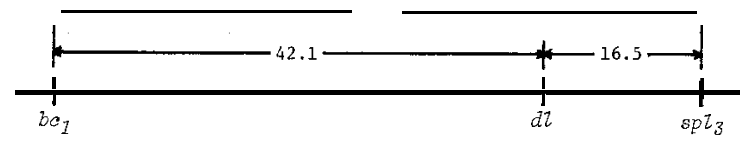

Fig. 2. Linkage map of the group XI. 
$43.0 \%$ from the data of repulsion phase. Because the linkage intensity between $d l$ and $b c$, is about $40 \%$ (Iwata and Omura, $1971 \mathrm{~b}$ ), the sequence of the three genes at the map of the linkage group XI is probably $b c_{1}-d l-s p l_{3}$ (Fig. 2).

$s p l_{4}$ : Intimate linkage relations were observed between $s p l_{1}$ and such two genes as $d p_{\mathrm{i}}$ and wx belonging to the linkage group I. As shown in Table 6, linkage intensities of $s p l_{4}-d p_{1}$ were estimated from $F_{2}$ in coupling phase and two kinds of $F_{3}$ lines from $F_{2}$ plants in repulsion phase showing such phenotypes as $s p l_{4}{ }^{+} d p_{1}$ and $s p l_{4} d p_{1}{ }^{+}$at $3.0 \%, 0.8 \%$ and $3.4 \%$, respectively. The weighted mean was calculated at $2.5 \%$ from these values. The linkage intensity of $s p l_{4}-w x$ was also estimated from $\mathrm{F}_{2}$ in repulsion phase at $2.3 \%$. The linkage relation between $d p_{1}$ and $w x$ with intensity of $2.2 \%$ have been recognized previously (Nagamatsu and Omura, 1962). Therefore, it is obvious that the three genes, $s p l_{4}, d p_{1}$ and $w x$, are nearly located each other at the map of the linkage group I, notwithstanding the sequence of them is not yet confirmed.

Table 6. Linkage relations between spl, and genes belonging to the linkage group I.

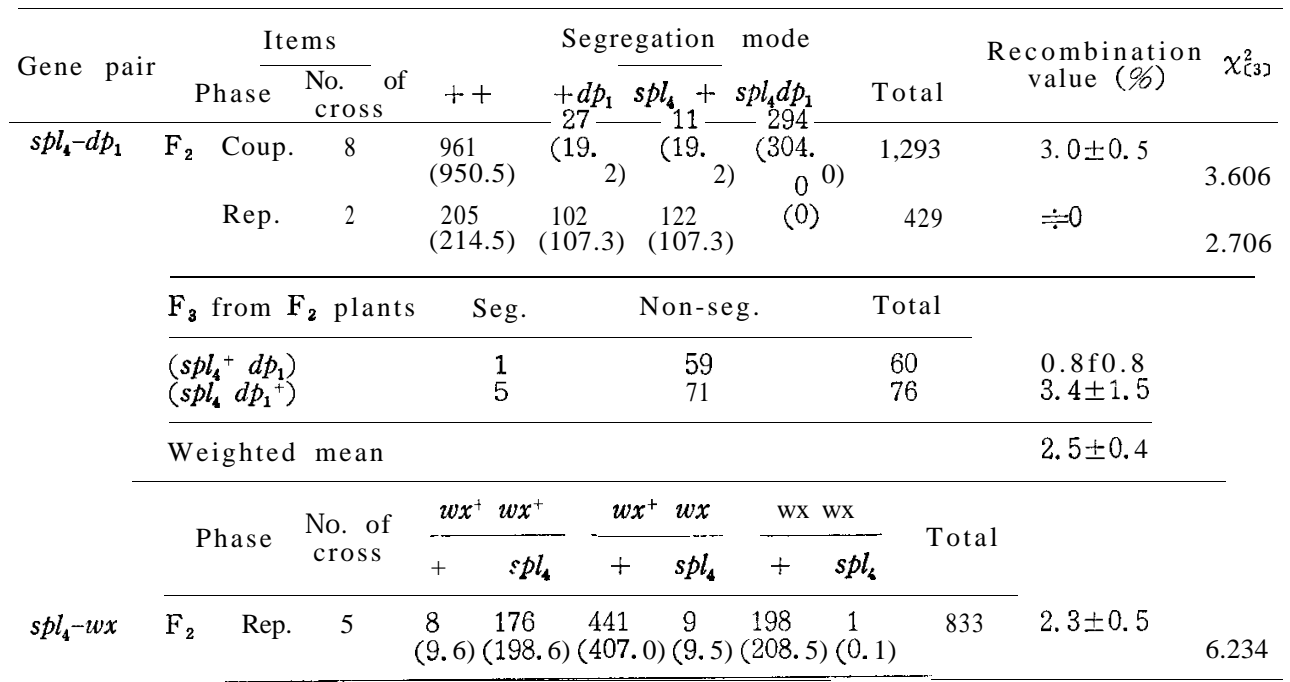

$s p l_{5}$ : The linkage relationships between the $s p l_{5}$ and such three genes as $d, g$ and $R c$ belonging to the linkage group IV were observed. From $\mathrm{F}_{2}$

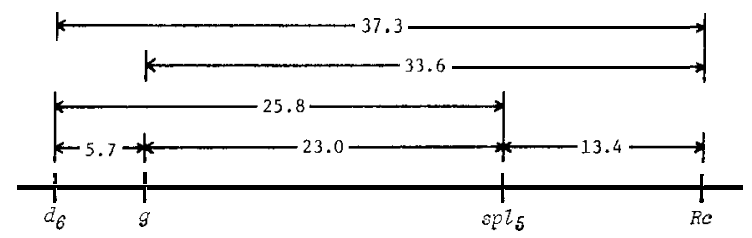

Fig. 3. Linkage map of the group IV. 
Table 7. Linkage relations between $s p l_{5}$ and genes belonging to the linkage group IV.

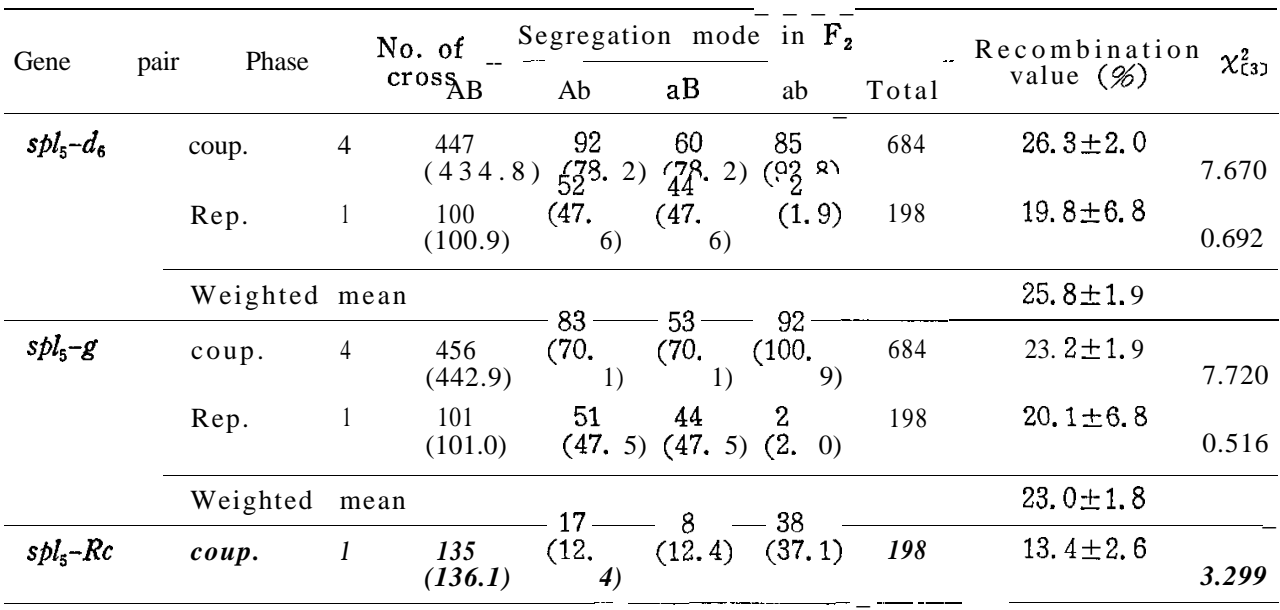

Table 8. Linkage relations between $s p l_{6}$ and genes belonging to the linkage group III.

\begin{tabular}{|c|c|c|c|c|c|c|c|c|c|}
\hline \multirow[b]{2}{*}{ Gene pai } & \multicolumn{2}{|c|}{ Items } & \multicolumn{5}{|c|}{ Segregation mode } & \multirow{2}{*}{$\begin{array}{c}\text { Recombination } \\
\text { value }(\mathscr{\phi})\end{array}$} & \multirow{2}{*}{$x_{[3]}^{2}$} \\
\hline & Phase & $\begin{array}{l}\text { No. of } \\
\text { cross }\end{array}$ & ++ & $+e g$ & $s p l_{6}+$ & $s p l_{6}$ eg & Total & & \\
\hline \multirow[t]{6}{*}{$s p l_{6}-e g$} & $\mathrm{~F}_{2}$ Coup. & 4 & $\begin{array}{c}560 \\
(550.0)\end{array}$ & (29. & (29. & $(164$. & 772 & $7.8 \pm 1.0$ & 1.124 \\
\hline & Rep. & 2 & $\begin{array}{c}225 \\
(220)\end{array}$ & $\begin{array}{l}110 \\
(110)\end{array}$ & $\begin{array}{c}105 \\
(110)\end{array}$ & $(0)$ & 440 & $\doteqdot 0$ & 0.341 \\
\hline & $F_{3}$ from & $F_{2}$ plants & Seg. & & Non-seg. & & Total & & \\
\hline & $\begin{array}{l}\left(s p l_{6}^{+}\right. \\
\left(s p l_{6} e\right.\end{array}$ & & $\begin{array}{l}18 \\
16\end{array}$ & & $\begin{array}{l}66 \\
89\end{array}$ & & $\begin{array}{r}84 \\
105\end{array}$ & $\begin{array}{c}12.0 \pm 2.8 \\
8.3 t 2.1\end{array}$ & \\
\hline & Weighte & mean & & & & & & $8.3 \pm 0.9$ & \\
\hline & Phase & $\begin{array}{l}\text { No. of } \\
\text { cross }\end{array}$ & ++ & $\begin{array}{l}+\operatorname{lax} \\
-3 \\
\end{array}$ & $s p l_{6}+s p l_{6}$ & $l_{6}-48^{\operatorname{lax}}$ & Total & & \\
\hline \multirow[t]{6}{*}{$s p l_{6}-l a x$} & $\mathrm{~F}_{2}$ Coup. & 1 & $\begin{array}{l}125 \\
(130.8)\end{array}$ & (1.9) & $(1.9)$ & $\begin{array}{c}(42.3) \\
2\end{array}$ & 177 & $2.2 \pm 1.1$ & 2.070 \\
\hline & Rep. & 6 & $\begin{array}{l}552 \\
(556.0)\end{array}$ & $\begin{array}{l}264 \\
(275.0)\end{array}$ & $\begin{array}{l}290 \\
(275.0)\end{array}$ & $(2$. & 1,108 & $8.4 \pm 3.0$ & 1.286 \\
\hline & $F_{s}$ from & $\mathrm{F}_{2}$ plants & Seg. & & Non-seg. & & Total & & \\
\hline & $\begin{array}{l}\left(s p l_{6}{ }^{+} s_{6}\right. \\
\left(s p l_{6} l\right.\end{array}$ & & 23 & & 173113 & & 194136 & $5.7 \pm 1.9 .2 \pm 1.92$ & \\
\hline & Weighte & mean & & & & & & $4.9 \pm 0.7$ & \\
\hline & Phase & $\begin{array}{c}\text { No. of } \\
\text { cross }\end{array}$ & $\mathrm{AB}$ & $\mathrm{Ab}$ & $\mathrm{aB}$ & $\begin{array}{r}a b \\
-1\end{array}$ & Total & & \\
\hline$s p l_{6}-d_{10}$ & $F_{2}$ Rep. & 3 & $\begin{array}{l}283 \\
(279.0)\end{array}$ & $\begin{array}{l}130 \\
(138.0)\end{array}$ & $\begin{array}{l}142 \\
(138.0)\end{array}$ & $3^{n}$ & 556 & $8.7 \pm 4.2$ & 0.635 \\
\hline$s p l_{6}-A$ & $\mathrm{~F}_{2}$ Coup. & 3 & $\begin{array}{l}287 \\
(309.3)\end{array}$ & $\begin{array}{l}126 \\
(107.7)\end{array}$ & $\begin{array}{l}105 \\
(107.7)\end{array}$ & $(31.3)$ & 556 & $52.6 \mathrm{f} 3.3$ & 6.220 \\
\hline
\end{tabular}


data shown in Table 7 , the recombination values of $s p l_{5}-d_{6}, s p l_{5}-g$ and $s p l_{5}-R c$ were estimated at $25.8 \%, 23.0 \%$ and $13.4 \%$, respectively. The recombination values of $d_{6}-g, g-R c$ and $d_{6}-R c$ have previously been calculated at $5.7 \%$, $33.6 \%$ and $37.3 \%$, respectively (Iwata and Omura, $1971 \mathrm{~b}$ ). Thus, the sequence of the four genes at the map may be $d_{6}-g-s p l_{5}-R c$ (Fig 3).

$s p l_{6}$ : Regarding $s p l_{6}$, the linkage relations were observed with four genes of eg, lax, $d_{10}$ and A belonging to the linkage group III (Table 8). The recombination values of $s p l_{6}-\rho g$ were estimated from $F_{2}$ in coupling phase and two kinds of $\mathrm{F}_{3}$ lines from $\mathrm{F}_{2}$ in repulsion phase at $7.8 \%, 12.0 \%$ and $8.3 \%$, respectively, and resulted in the weighted mean of $8.3 \%$. The recombination values of $s p l_{6}-l a x$ were estimated at $2.2 \%$ and $8.4 \%$ from $\mathrm{F}_{2}$ in both coupling and repulsion phase and at $5.7 \%$ and $9.2 \%$ from two kinds of $\mathrm{F}_{3}$ 's from $\mathrm{F}_{2}$ in repulsion phase. respectively, and thus their weighted mean of $4.9 \%$ was obtained. The recombination values of $s p l_{6}-d_{10}$ and $s p l_{6}-A$ were also estimated from $\mathrm{F}_{2}$ at $8.7 \%$ and $52.6 \%$, respectively. The arrangement of $e g-l a x-d_{10}-A$ on the group and linkage intensities between them have previously been confirmed (Iwata and Omura, 1971 a). Thus, the sequence of the five genes at the map of linkage group III would be $e g-s p l_{6}-l a x-d_{10}-A$ (Fig. 4).

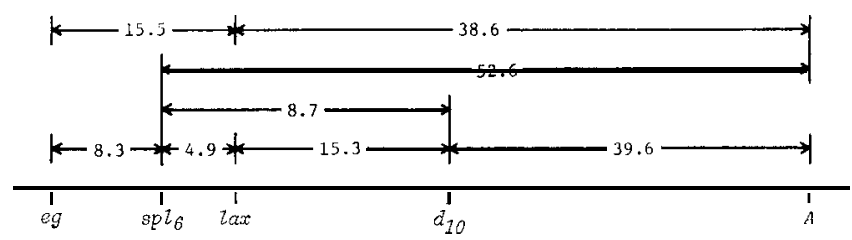

Fig. 4. Linkage map of the group III.

Table 9. Linkage relations between $s p l_{7}$ and genes belonging to the linkage group IX.

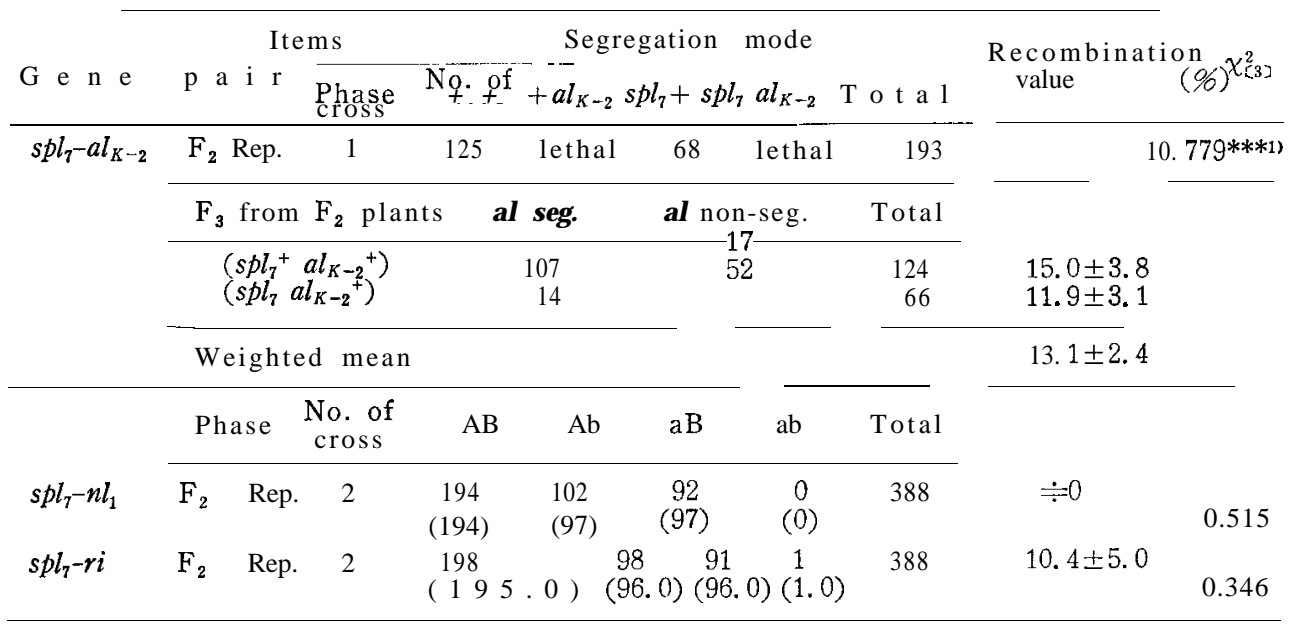

1) $\chi^{2}$ in this cross was for 3: 1. and then begree of freedom was 1 .

*** Significant at $0.1 \%$ level. 
$s p l_{7}$ : The linkage relations were observed between $s p l_{7}$ and such three genes as $a l_{,}{ }_{2}, n l_{1}$ and $r i$ belonging to the linkage group IX (Table 9). Since homozygous plants for the $a l_{K-2}$ gene are lethal at the seedling stage (Iwata and Omura, 1978), only two of phenotypes survived in $\mathrm{F}_{2}$ of the cross between $s p l_{7}$ and $a l_{-2}$ were examined for segregation mode of $s p l_{7}$. The mode deviated remarkably from 3: 1 ratio, suggesting a existence of linkage relation between them. The recombination values of $15.0 \%$ and $11.9 \%$ were estimated from the progeny test of $\mathrm{F}_{2}$ plants having the phenotypes of $s p l_{7}{ }^{+} a l_{K-2}{ }^{+}$and $s p l_{7} a l_{K-2}{ }^{+}$, respectively, and their weighted mean of $13.1 \%$ was obtained. Between $s p l_{7}$ and $n l_{1}$, a very close linkage relation was assumed from the fact that non of the doubly recessive plant had been observed in $F_{2}$ in the cross of repulsion phase, though the recombination value could not be given. In the cross between $s p l_{7}$ and $r i$, only one of doubly recessive plant had been observed in $\mathrm{F}_{2}$ in repulsion phase and thus a linkage intensity was estimated at $10.4 \%$. Although it needs additional data for confirming a accurate sequence of the four genes, the order of $a l_{, 2}{ }_{2}-n l_{1}-s p l_{7}-r i$ at the map of linkage group IX was adopted tentatively.

$s p l_{3}$ : Phenotypic characteristics of $s p l_{8}$ having fine striped spots of reddish brown on leaves is different clearly from that of any other $s p l$ genes described in this paper, and the linkage relation was observed between $s p l_{3}$ and $s p l_{2}$ with the intensity of 13.6 of from $\mathrm{F}_{2}$ in the cross of repulsion phase (Table 10). Consequently, it is considered that $s p l_{8}$ also belongs to the linkage group IX.

Table 10. Linkage relation between $s p l_{8}$ and $s p l_{7}$.

\begin{tabular}{|c|c|c|c|c|c|c|c|c|}
\hline Phase & $\begin{array}{c}\text { No. of } \\
\text { cross }\end{array}$ & ++ & $\begin{array}{l}\text { egregat } \\
+s p l_{7}\end{array}$ & $\begin{array}{l}\text { on } \bmod \\
s p l_{8}+\end{array}$ & $\begin{array}{l}\text { e in } \mathrm{F}_{2} \\
s p l_{8} s p l_{7}\end{array}$ & Total & $\begin{array}{c}\text { Recombination } \\
\text { value }(\%)\end{array}$ & $\chi_{[3]}^{2}$ \\
\hline Rep. & 1 & $\begin{array}{l}107 \\
(107.5)\end{array}$ & $\begin{array}{r}49 \\
(52 . \\
(3)\end{array}$ & $\begin{array}{c}56 \\
(52.3)\end{array}$ & $\begin{array}{l}1- \\
(0 . \\
9)\end{array}$ & 213 & $13.6 \pm 6.7$ & 473 \\
\hline
\end{tabular}

Table 11. Segregations for normal vs. physiological leaf spots $\left(s p l_{9}\right)$ in $\mathrm{F}_{2}$ lines between linkage testers and a mutant strain (LT 26) showing physiological leaf spots.

\begin{tabular}{|c|c|c|c|c|}
\hline+ & $s p l_{9}$ & Total & $x^{2}$ & for $3: 1$ \\
\hline 151 & 49 & 195 & & 0.617 \\
\hline 146 & & 195 & & 0.002 \\
\hline 147 & 47 & 191 & & 0.393 \\
\hline 141 & 40 & 188 & & 0.000 \\
\hline 148 & & 188 & & 1. 390 \\
\hline 150 & 45 & 194 & & 0.557 \\
\hline 146 & 39 & 191 & & 0.211 \\
\hline 152 & & 191 & & 2.138 \\
\hline 181 & 352 & 1,533 & & 3.397 \\
\hline
\end{tabular}

$s p l_{9}$ : Blackish brown spots of this mutant is unique in feature. Segregation modes of normal to this character in $\mathrm{F}_{2}$ were accordant with a ratio 
of 3: 1, indicating that the character was controlled by a single recessive gene, $s p l_{9}$ (Table 11). However, the linkage group to which $s p l_{9}$ belongs is so far unknown.

As described above, the linkage studies with nine of $s p l$ genes expressing spotted leaf were made in this paper, and with eight of them the linkage groups to which they belonged were proved. Three genes, $s p l_{3}, s p l_{5}$ and $s p l_{7}$ were so similar that they could not be distinguished by their phenotypic feature, nevertheless they were controlled by different genes and belonged to different linkage groups. The same was observed between $s p l_{4}$ and $s p l_{6}$. Therefore, it is well considerable that there are many mutants even if they have similar phenotype. A hundred and one of spotted leaf mutants have been collected in our laboratory, so the identification of genes and the linkage analysis are carrying on.

\section{REFERENCES}

Iwata, N. and T. Omura 1971 a Linkage analysis by reciprocal translocation method in rice plants (Oryza sativa L.) I. Linkage groups corresponding to the chromosome 1. 2, 3 and 4. Japan. J. Breed., 21: 19-28 (in Japanese with English summary)

Iwata, N. and T. Omura 1971 b Linkage analysis by reciprocal translocation method in rice plants (Oryza sativa L.) II. Linkage groups corresponding to the chromosome 5, 6, 8, 9, 10 and 11. Sci. Bull. Fac.Agr., Kyushu Univ., 25: 137-153 (in Japanese with English summary)

Iwata, N. and T. Omura 1975 Studies on the trisomics in rice plants (Oryza sativa L.) III. Relation between trisomics and genetic linkage groups. Japan. J. Breed., 25: 363-368

Iwata, N. and T. Omura 1977 Linkage studies in rice (Oryza sativa L.). On some mutants derived from chronic gamma irradiation. J. Fac. Agr., Kyushu Univ., 21: 117-127

Iwata. N. and T. Omura 1978 Linkage studies in rice (Oryza sativa L.). Some albino genes and their linkage relation between marker genes. Sci. Bull. Fac. Agr., Kyushu Univ., 33 (in press) (in Japanese with English summary)

Jones, J. W. 1952 Inheritance of natural and induced mutations in Caloro rice and observations on sterile Caloro types. J. Hered., 43: 81-85

Nagamatsu, T. and T. Omura 1962 Linkage study of the genes belonging to the first chromosome in rice. Japan. J. Breed.. 12: 231-236

Nagao, S. and M. Takahashi 1963 Trial construction of twelve linkage groups in Japanese rice. (Genetical studies on rice plant. XXVII). J. Fac. Agr., Hokkaido Univ., 53: $72-130$

Nagao, S., M. Takahashi and K. Morimura 1964 Genetical studies on rice plant, XXVIII. Causal genes and their linkage relationships of some morphological characters, introduced from foreign rice varieties. Mem. Fac.Agr., Hokkaido Univ., 5: 89-96 (in Japanese with English summary)

Omura, T. and N. Iwata 1972 Linkage studies in rice. On the linkage groups 8,10 and 11. Japan. J. Breed., 22 (Supl. 1): 43-44 (in Japanese)

Takahashi, M., T. Kinoshita and K. Takeda 1968 Character expressions and causal genes of some mutants in rice plant. (Genetical studies on rice plant, XXXIII). J. Fac. Agr., Hokkaido Univ., 55: 496-512 